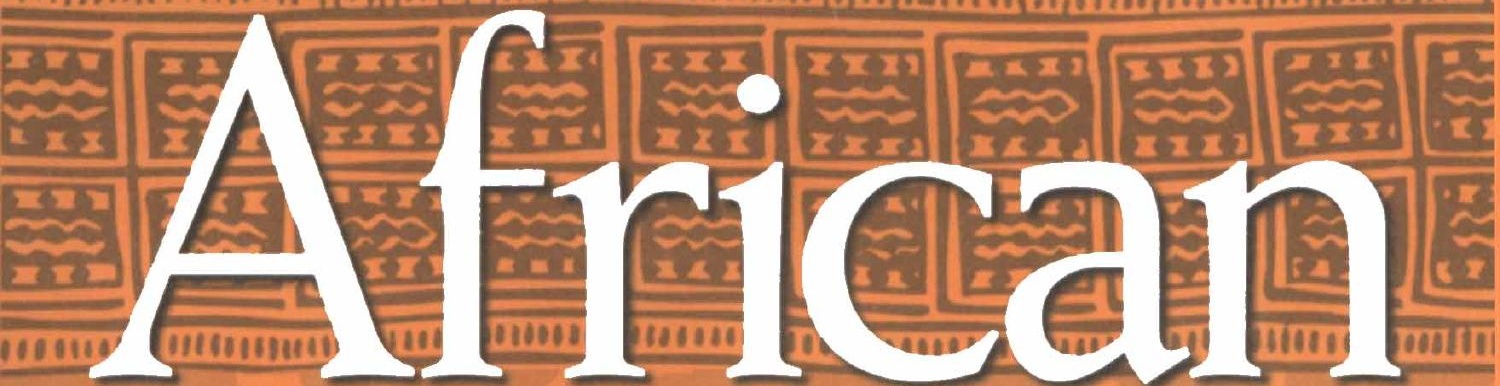

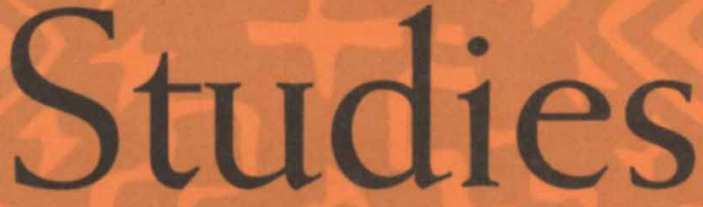

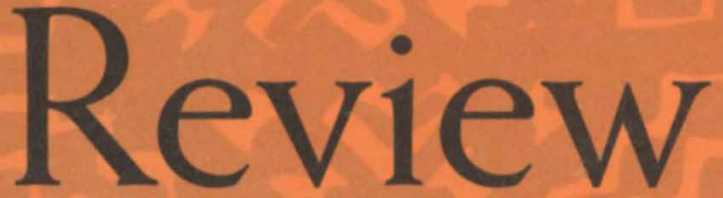

PUBLISHED BY THE AFRICAN STUDIES ASSOCIATION
Judith A. Byfield

Gender, Justice, and the Environment

ASR Focus: The Political Economy of Democratic Reform in Kenya

John W. Harbeson

Karuti Kanyinga and James D. Long

Mwangi wa Githīnji and

Frank Holmquist

Catherine Boone

ASR Forum: Decolonization in the Congo (DRC) - Fifty Years Later

Kasongo M. Kapanga

Herbert Weiss

Michael G. Schatzberg

Patience Kabamba

David Newbury

Seifudein Adem

China in Ethiopia

Dillon Mahoney

Changing Strategies in Marketing

Kenya's Tourist Art

Commentary

On the Somalia Dilemma

In Memoriam

Ivan Karp (1943-2011)

Review Essay

Book and Film Reviews 


\section{African Studies Association The Journal of the African Studies Association}

\section{African Studies Review}

706 Herter Hall

161 Presidents Drive

University of Massachusetts

Amherst, MA 01003 USA

VOICE: $413-545-2065$

E-MAIL:

asr@anthro.umass.edu

WEB SITE:

wuw.umass.edu/anthro/asr

\section{Editorial Board}

Rowland Abiodun

Amherst College

Elias Bongmba

Rice University

Stephen Clingman

University of Massachusetts-Amherst

Mamadou Diouf

Columbia University

Peter Geschiere

University of Amsterdam

Sandra Greene

Comell University

Jane Guyer

Johns Hopkins University

Tabitha Kanogo

University of California-Berkeley

V. Y. Mudimbe

Duke University

Francis Nyamnjoh

University of Capetown

Anne Pitcher

Colgate University

Judith Van Allen

Cornell University

Michael Watts

University of California-Berkeley

\section{Editors}

Ralph Faulkingham

Editor Emeritus

University of Massachusetts Amherst

Elliot Fratkin

Smith College

Mitzi Goheen

Amherst College

Sean Redding

Amherst College

\section{Managing Editor and Copy Editor}

Ella Kusnetz

\section{Book Review Editor}

John Lemly

Mount Holyoke College

50 College St.

South Hadley, MA 01075 USA

VOICE: $413-538-2448$

E-MAlt: asr-book@mtholyoke.edu

\section{Film Review Editor}

Kenneth Harrow

17R Morrill Hall

Michigan State University

East Lansing, Ml 48824-1036 USA

VOICE: $517-803-8839$

E-MAIL: harrow@msu.edu

\section{Production Editor}

Craig Malone

Books for review should be sent to the book review editor. The African Studies Review does not accept unsolicited book or film reviews. 


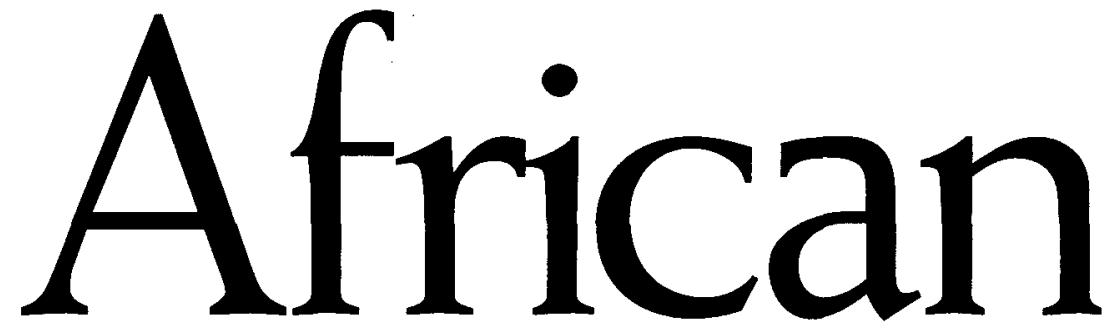

Studies Review

VOLUME 55, NUMBER 1

APRIL 2012

\section{African Studies Association \\ Rutgers University \\ 54 Joyce Kilmer Avenue \\ Piscataway, NJ 08854-8045 USA}




\section{NOTICE TO MEMBERS}

The United States Postal System does not forward periodicals. We must receive written notification from you at least five weeks in advance of any change of mailing address. Failure to notify us of your correct mailing address will result in suspension of your membership mailings until we receive such notification. We can make address changes only when current dues are paid. Domestic claims for non-receipt of issues must be made to the Association's office within six months of publication (overseas claims, one year). Copies of the Review damaged in the mail will be replaced without charge.

The African Studies Review is published three times a year (April, September, and December) by the African Studies Association, Rutgers University, 54 Joyce Kilmer Avenue, Piscataway, NJ 08854-8045, USA. Articles in the Review represent neither the views of the African Studies Association nor those of its officers; responsibility for opinions expressed and for the accuracy of facts published rests solely with the individual authors.

Cㄱ 2012 African Studies Association

All rights reserved.

ISSN 0002-0206

No part of this publication may be reproduced (in any form and by any means) without permission of the African Studies Association (ASA) via its registered copyright agent, Copyright Clearance Center. Information on the different types of permissions available and the associated royalties may be found online at www.copyright.com (search for African Studies Review). Once permission is secured, whether for republication in whole or in part, publishers also must acknowledge prior publication in the African Studies Review by author, title, volume, number, date, and inclusive pagination.

Authors whose works are published in ASA journals may duplicate and distribute their own works to their own classes, to their own Web sites, or to their own institution's Web site without seeking the publisher's permission, but they must cite details of publication in the specific journal by author, title, volume, number, date, and inclusive pagination.

ASA members who wish to duplicate and distribute articles published in any ASA journal for their own courses may do so without seeking permission from the ASA, but they must cite details of publication in the specific journal by author, title, volume, number, date, and inclusive pagination. 


\section{African Studies Review}

VOLUME 55, NUMBER 1, APRIL 2012

IV From the Editors

1 Gender, Justice, and the Environment: Connecting the Dots Judith A. Byfield

\section{ASR Focus: The Political Economy of Democratic Reform in Kenya}

13 Introduction

John W. Harbeson

15 Land and the Quest for a Democratic State in Kenya:

Bringing Citizens Back In

John W. Harbeson

31 The Political Economy of Reforms in Kenya: The Post-2007 Election Violence and a New Constitution

Karuti Kanyinga and James D. Long

53 Reform and Political Impunity in Kenya: Transparency without Accountability

Mwangi wa Gĩthĩnji and Frank Holmquist

75 Land Conflict and Distributive Politics in Kenya Catherine Boone

ASR Forum: Decolonization in the Congo (DRC)Fifty Years Later

105 Introduction

Kasongo M. Kapanga

109 The Congo's Independence Struggle Viewed Fifty Years

Later

Herbert Weiss

117 The Structural Roots of the DRC's Current Disasters: Deep Dilemmas

Michael G. Schatzberg

Published by the African Studies Association 
123 External Economic Exploitation in the DRC: 1990-2005 Patience Kabamba

131 The Continuing Process of Decolonization in the Congo: Fifty Years Later

David Newbury

143 China in Ethiopia: Diplomacy and Economics of Sino-optimism Seifudein Adem

161 Changing Strategies in Marketing Kenya's Tourist Art: From Ethnic Brands to Fair Trade Labels

Dillon Mahoney

\section{COMMENTARY}

191 On the Somalia Dilemma: Adding Layers of Complexity to an Already Complex Emergency

Peter D. Little

\section{IN MEMORIAM}

197 Ivan Karp (1943-2011)

T. O. Beidelman

\section{REVIEW ESSAY}

\section{THE SUDANS IN THE TWENTY-FIRST CENTURY}

Joseph O. Abulemoi. The Fragility of Sudan: A Study of the Comprehensive Peace Agreement.

J. Millar Burr and Robert O. Collins. Sudan in Turmoil: Hasan al-Turabi and the Islamist State.

Elke Grawert, ed. After the Comprehensive Peace Agreement in Sudan. Randall Fegley. Beyond Khartoum: A History of Subnational Government in Sudan.

Abdullahi A. Gallab. A Civil Society Deferred: The Tertiary Grip of Violence in the Sudan.

Douglas H. Johnson. The Root Causes of Sudan's Civil Wars: Peace or Truce.

John Ryle, Justin Willis, Suliman Baldo, and Jok Madut Jok, eds. The Sudan Handbook.

M. W. Daly 


\section{BOOK REVIEWS}

\section{ANTHROPOLOGY AND SOCIOLOGY}

211 David McDermott Hughes. Whiteness in Zimbabwe: Race, Landscape, and the Problem of Belonging.

Léa Kalaora

213 Gracia Clark. African Market Women: Seven Life Stories from Ghana. Claire Robertson

\section{HISTORY}

215 Peter Alegi. Laduma! Soccer, Politics and Society in South Africa, from Its Origins to 2010.

Peter Alegi. African Soccerscapes: How a Continent Changed the World's Game.

Todd Cleveland

\section{POLITICS, INTERNATIONAL RELATIONS, AND GLOBALIZATION}

219 lan Scoones, et al. Zimbabwe's Land Reform: Myths and Realities. Amanda Hammar

221 Daniel Compagnon. A Predictable Tragedy: Robert Mugabe and the Collapse of Zimbabwe.

Sabelo J. Ndlovu-Gatsheni

223 Susanna D. Wing. Constructing Democracy in Transitioning Societies of Africa: Constitutionalism and Deliberation in Mali. Jennifer C. Seely

\section{HEALTH ANDD DISEASE}

225 Claire L. Wendland. A Heart for the Work: Journeys through an African Medical School.

Rebecca Warne Peters

\section{LANGUAGES, LITERATURE, AND THE ARTS}

227 Marissa J. Moorman. Intonations: A Social History of Music and Nation in Luanda, Angola, from 1945 to Recent Times.

Bob W. White

\section{FILM REVIEW}

229 A Time There Was/En ceTemps-là.

Eugenia W. Herbert

\section{BOOKS RECEIVED}

